\title{
Preparation of $\mathrm{La}_{0.3} \mathrm{Sr}_{0.7} \mathrm{CoO}_{3-\delta}$ perovskite by thermal decomposition of metal-EDTA complexes
}

\author{
René H. E. van Doorn, ${ }^{\dagger}$ Henk Kruidhof,* Arian Nijmeijer, Louis Winnubst and \\ Anthony J. Burggraaf \\ University of Twente, Faculty of Chemical Technology, Laboratory for Inorganic Materials \\ Science, P.O. Box 217, NL-7500 AE Enschede, The Netherlands
}

Perovskite powders of $\mathrm{La}_{0.3} \mathrm{Sr}_{0.7} \mathrm{CoO}_{3-\delta}$ were prepared by the thermal decomposition of precursor complexes derived from nitrate solutions using ethylenediaminetetraacetic acid (EDTA) as a complexing agent. The calcination temperature is $920{ }^{\circ} \mathrm{C}$. Powders thus obtained have a low carbon contamination. Dense ceramics with a relative density of about $96 \%$ have been prepared after sintering at $1150^{\circ} \mathrm{C}$.

\section{Introduction}

There is currently considerable interest in the chemical and physical properties of $\mathrm{La}_{1-x} \mathrm{Sr}_{x} \mathrm{CoO}_{3-\delta}$ due to potential applications in the fields of catalysis, ${ }^{1}$ dense ceramic membrane, ${ }^{2,3}$ oxide fuel cell electrodes ${ }^{4}$ and giant magnetic resistance. ${ }^{5}$ At present, powders of these materials are often prepared by conventional solid state reaction, e.g., of the respective binary oxides, metal carbonates, hydroxides, cyanides or nitrates, a method which is characterized by laborious milling, high temperature treatment and regrinding. The powders thus obtained are often contaminated with one or more of the unreacted reactants and/or abrasives of the grinding media, frequently resulting in inhomogeneities and a bad sintering ability.

More advanced techniques rely on the physical or chemical immobilization of metal precursors, including freeze drying, sol-gel, coprecipitation, Pechini or modified-Pechini methods. These methods all maintain the metal precursors in a highly dispersed state. In general, they lead to more homogeneous powders at relatively low temperatures.

In this paper, attention will be focused towards the preparation of $\mathrm{La}_{0.3} \mathrm{Sr}_{0.7} \mathrm{CoO}_{3-\delta}$, a material which is being investigated in our laboratory for use as a dense ceramic membrane in the separation of oxygen from air. ${ }^{2,3}$ To improve its homogeneity and sinterability a wet chemical preparation method has been employed in this study, consisting of the following steps: (i) complexation of the metal ions in ethylenediaminetetraacetic acid (EDTA) solution, (ii) evaporation of the water solvent, (iii) thermal decomposition of the complex and formation of the perovskite phase. EDTA was chosen as the complexing agent since it is known to exhibit strong complexing ability for almost every metal ion. It thus prevents partial segregation of metal components, which would occur in the case of different stabilities with the metal ions in solution. Adjusting the value of the $\mathrm{pH}$ can easily control the degree of complexation. We have succeeded in the preparation of highpurity $\mathrm{La}_{0.3} \mathrm{Sr}_{0.7} \mathrm{CoO}_{3-\delta}$. The route followed has not been described in detail in the literature before. Additional work in our laboratory has indicated that, with minor adaptation of the $\mathrm{pH}$ value and sintering temperature, it presents a reliable route for the preparation of dense perovskite ceramics having compositions $\mathrm{La}_{1-x} \mathrm{Sr}_{x} \mathrm{Co}_{1-y} \mathrm{Fe}_{y} \mathrm{O}_{3-\delta}$.

$\dagger$ Present address: Air Products and Chemicals Inc., 7201 Hamilton Boulevard, Allentown, PA 18195-1501 USA.

E-mail: vandoorn@apci.com.

\section{Experimental}

All chemicals were obtained from Merck Chemicals and were of p.a. quality $(>99.0 \%)$. Since the nitrates $\operatorname{Sr}\left(\mathrm{NO}_{3}\right)_{2}$, $\mathrm{Co}\left(\mathrm{NO}_{3}\right)_{3} \cdot 6 \mathrm{H}_{2} \mathrm{O}$ and $\mathrm{La}\left(\mathrm{NO}_{3}\right)_{3} \cdot 6 \mathrm{H}_{2} \mathrm{O}$ are very hygroscopic, standardized solutions of $1-1.7 \mathrm{M}$ in $\mathrm{Q}_{2}$-distilled water were used.

A $25 \%$ ammonia solution was added to EDTA until the latter was completely dissolved. The metal nitrate solutions were mixed in appropriate amounts. To this solution the $\mathrm{NH}_{4}-$ EDTA was added. The colour of the solution darkened to deep purple due to the complexation of the Co ion. The molar ratio of metal to EDTA in the final solution was $1: 1.5$. The $\mathrm{pH}$ was adjusted to $\mathrm{pH} \approx 8-9$ with ammonia, which resulted in a clear solution. Approximately $200 \mathrm{ml}$ of this solution were evaporated in a porcelain dish in a furnace which was kept at $250^{\circ} \mathrm{C}$. After evaporation a spontaneous ignition of the formed foam (pyrolysis) occurred in the same furnace, and a fluffy ash was obtained. This ash was calcined at different temperatures $\left(300-1100^{\circ} \mathrm{C}\right)$ for $0.5-5 \mathrm{~h}$ under either stagnant air or under a flow of pure oxygen $[50 \mathrm{ml}$ (STP) $\left.\min ^{-1}\right]$

Thermal decomposition behaviour of the uncalcined powders was studied using combined TGA-DSC (Stanton Redcroft STA625) on 10-20 mg samples with an air or oxygen

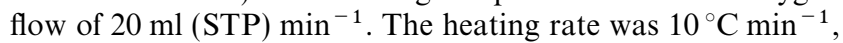
while $\alpha-\mathrm{Al}_{2} \mathrm{O}_{3}$ was used as a reference. Calcined powders were analyzed by means of XRD (Philips PW1710) using Ni-filtered $\mathrm{Cu}-\mathrm{K} \alpha$ radiation $(\lambda=1.5408 \AA$ ), SEM (JEOL JSM $35 \mathrm{CF}$ at 15 and $25 \mathrm{keV}$ ). Structural analysis was performed using a powder calcined at $1100{ }^{\circ} \mathrm{C}$ with $\mathrm{LaB}_{6}$ as internal standard. Crystal size analysis was done by XRD half width peak analysis $(2 \theta=$ $33.03^{\circ}$ ) using yttria-stabilized zirconia as a reference. The Voigt correction for internal stress and correction for $\mathrm{K} \alpha_{1,2}$ splitting was carried out using the program NTRACES. ${ }^{6}$ Particle size distribution measurements were performed using laser scat-

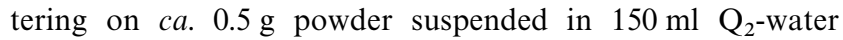
(Horiba LA-500). The carbon, nitrogen and hydrogen contents were determined by full oxidation with $\mathrm{V}_{2} \mathrm{O}_{5}$ and $\mathrm{O}_{2}$, followed by the determination of the formed amounts of $\mathrm{CO}_{2}, \mathrm{NO}_{x}$ and $\mathrm{H}_{2} \mathrm{O}$ by means of gas chromatography. The elemental composition was checked by means of a chelating titration using EDTA.

Prior to preparation of dense ceramics, $15 \mathrm{~g}$ of powders calcined at 920 or $950{ }^{\circ} \mathrm{C}$ were dry ball milled for $2 \mathrm{~h}$, using 15 stabilized zirconia balls of $15 \mathrm{~mm}$ diameter in a $250 \mathrm{ml}$ polyethylene container at $55 \mathrm{rpm}$. Ceramic rods $(3 \mathrm{~g}$ powder, $20 \mathrm{~mm}$ in diameter) were prepared by uniaxial pressing at $1.5 \times 10^{6} \mathrm{~Pa}$, followed by cold isostatic pressing at $400 \mathrm{MPa}$. 
Table 1 Powder characteristics as a function of calcination temperature

\begin{tabular}{|c|c|c|c|c|c|c|c|c|}
\hline$T_{\text {calc }} /{ }^{\circ} \mathrm{C}$ & $\begin{array}{c}\mathrm{C} \\
\text { (wt.\%) }\end{array}$ & $\underset{\text { (wt.\%) }}{\mathrm{N}}$ & $\begin{array}{c}\mathrm{H} \\
\text { (wt.\%) }\end{array}$ & $\mathrm{La}_{2} \mathrm{O}_{3}$ & $\mathrm{SrCO}_{3}$ & Perovskite & $\mathrm{Co}_{3} \mathrm{O}_{4}$ & $\mathrm{NH}_{4} \mathrm{NO}_{3}$ \\
\hline uncalcined & 23.04 & 12.14 & 2.07 & - & + & - & - & + \\
\hline 300 & 9.92 & 4.20 & 0.61 & - & + & + & - & + \\
\hline 500 & 3.96 & 0.02 & 0.14 & - & + & + & - & - \\
\hline 600 & 3.48 & 0.03 & 0.08 & - & + & + & - & - \\
\hline 700 & 2.70 & 0.01 & 0.09 & - & + & + & - & - \\
\hline 850 & 0.25 & 0.08 & 0.06 & - & - & + & - & - \\
\hline 900 & 0.17 & 0.01 & 0.05 & - & - & + & - & - \\
\hline 1000 & 0.09 & 0.05 & 0.03 & - & - & + & - & - \\
\hline 1100 & 0.09 & 0.05 & 0.03 & - & - & + & - & - \\
\hline
\end{tabular}

These rods were sintered in air at temperatures between 950 and $1150{ }^{\circ} \mathrm{C}$ for $5 \mathrm{~h}$ with heating and cooling rates of $3.0^{\circ} \mathrm{C} \mathrm{min}{ }^{-1}$. Densities were determined by an Archimedes method using mercury.

\section{Results and Discussion}

\section{Synthesis}

During drying of the solution in the furnace, a black foam develops on top of the solution. On further heating, this foam spontaneously ignites. Pyrolysis occurs over the complete surface and is less vigorous than pyrolysis after complexation with citric acid. ${ }^{7}$ The application of $\mathrm{La}_{2} \mathrm{O}_{3}$ dissolved in $\mathrm{HNO}_{3}$ or $\mathrm{SrCl}_{2}$ as alternative precursors for the nitrates led to poor pyrolysis behaviour and poor powder morphology.

Experiments on powders calcined at $800^{\circ} \mathrm{C}$ for $0.5-5 \mathrm{~h}$ demonstrated that calcination time longer than $2 \mathrm{~h}$ had no further influence on the carbon content and phase composition of the powders. Chemical analysis showed the correct stoichiometry, indicating that no volatile metal compounds were formed during synthesis. Yields after calcination above $900{ }^{\circ} \mathrm{C}$ were over $97 \%$ of theoretical. A summary of the carbon, nitrogen and hydrogen analyses as well as the XRD results is given in Table 1.

\section{Calcination behaviour}

Fig. 1 shows a combined TGA-DSC run of an uncalcined powder in air. The small decrease in weight observed below $100^{\circ} \mathrm{C}$ is attributed to desorption of physically adsorbed water and carbon dioxide. A large decrease in weight is observed starting just below $300{ }^{\circ} \mathrm{C}$. This is accompanied by a large exothermic heat effect with an onset well below $300^{\circ} \mathrm{C}$ and centered at $370^{\circ} \mathrm{C}$, together with a small exothermic shoulder centered at $404^{\circ} \mathrm{C}$. Both peaks are attributed to the burnout of carbon and nitrogen (EDTA) and to the decomposition of $\mathrm{NH}_{4} \mathrm{NO}_{3}$. It is however not clear from these results which of these processes occurs first. The XRD patterns in Fig. 2

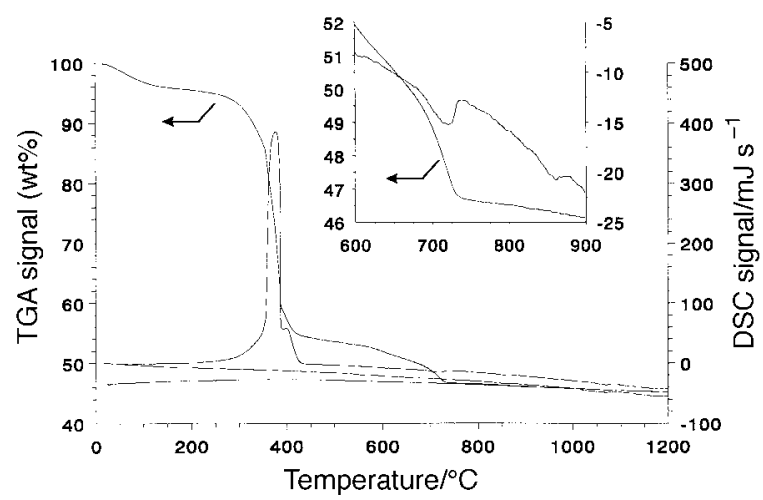

Fig. 1 Combined TGA-DSC run of uncalcined $\mathrm{La}_{0.3} \mathrm{Sr}_{0.7} \mathrm{CoO}_{3-\delta}$ powder in air

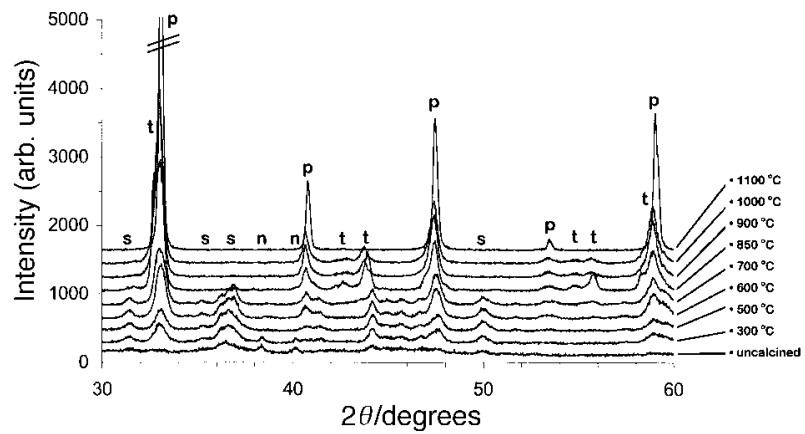

Fig. $2 \mathrm{X}$-Ray diffractograms from powders obtained after calcination at different temperatures: $\mathbf{n}, \mathrm{NH}_{4} \mathrm{NO}_{3} ; \mathbf{p}$, perovskite; $\mathbf{s}, \mathrm{SrCO}_{3} ; \mathbf{t}$, tetragonal perovskite

show the disappearance of the two peaks (at $2 \theta$ values of $38.3^{\circ}$ and $40.2^{\circ}$ ) attributed to $\mathrm{NH}_{4} \mathrm{NO}_{3}$ at temperatures above $300{ }^{\circ} \mathrm{C}$. Data on $\mathrm{N}$ and $\mathrm{H}$ contents (see Table 1 ) of the samples also suggest the decomposition of the $\mathrm{NH}_{4} \mathrm{NO}_{3}$ above $300^{\circ} \mathrm{C}$. Broad peaks belonging to the perovskite phase and to $\mathrm{SrCO}_{3}$ are already present in the XRD pattern of the powder calcined at $300{ }^{\circ} \mathrm{C}$.

A small endothermic heat effect is observed starting at $713{ }^{\circ} \mathrm{C}$ and centered at $738^{\circ} \mathrm{C}$, as shown in the inset of Fig. 1 . This peak corresponds to a heat effect of $33.4 \mathrm{~kJ} \mathrm{~mol}^{-1}$ and is accompanied by a weight loss of $5.8 \mathrm{wt} . \%$. The XRD patterns of powders calcined above $850{ }^{\circ} \mathrm{C}$ indicate that $\mathrm{SrCO}_{3}$ is no longer present. The observed phenomena have been attributed to the decomposition of $\mathrm{SrCO}_{3}$ into $\mathrm{SrO}$. The onset of this decomposition is, however, much lower than that $\left(845^{\circ} \mathrm{C}\right.$ under $\mathrm{N}_{2}$ ) observed by Scholten et al. ${ }^{8}$ The reason for the reduced onset temperature observed in this study may be the co-occurrence of the decomposition reaction of $\mathrm{SrCO}_{3}$ and the formation of the perovskite phase.

The XRD spectra of powders calcined above $850^{\circ} \mathrm{C}$ indicate that the main phase formed is of cubic perovskite symmetry. Some extra peaks, originating from a tetragonal perovskite phase, are present even up to the calcination temperature of $1000^{\circ} \mathrm{C}$. The tetragonal perovskite phase however was not always observed. The reason for this behaviour is not clear. Powders calcined at $1100{ }^{\circ} \mathrm{C}$ consist of the single cubic perovskite phase.

Powders calcined under flowing $\mathrm{O}_{2}$ showed, within experimental error, the same carbon and nitrogen content as powders calcined at the same temperature under stagnant air. The thermal decomposition behaviour in both cases was found to be similar.

In Fig. 3, the particle size distributions of calcined powders are given. Powders calcined at $700{ }^{\circ} \mathrm{C}$ mainly show large particles with a peak at $150 \mu \mathrm{m}$. Increasing the calcination temperature leads to smaller agglomerates. The bimodal distribution observed for powders calcined at $900^{\circ} \mathrm{C}$ transforms into a narrow particle size distribution for powders calcined at 1000 and $1100{ }^{\circ} \mathrm{C}$ having a maximum around $4.4 \mu \mathrm{m}$. Fig. 4 


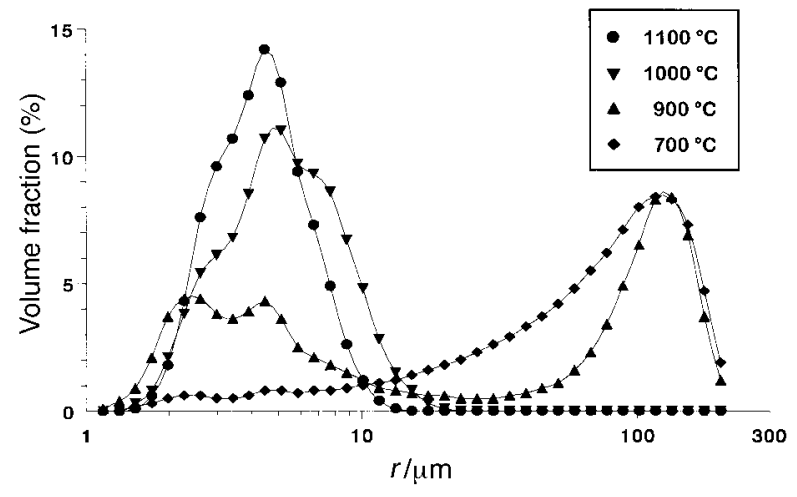

Fig. 3 Particle size distribution of $\mathrm{La}_{0.3} \mathrm{Sr}_{0.7} \mathrm{CoO}_{3-\delta}$ powder calcined at the indicated temperatures obtained by laser scattering

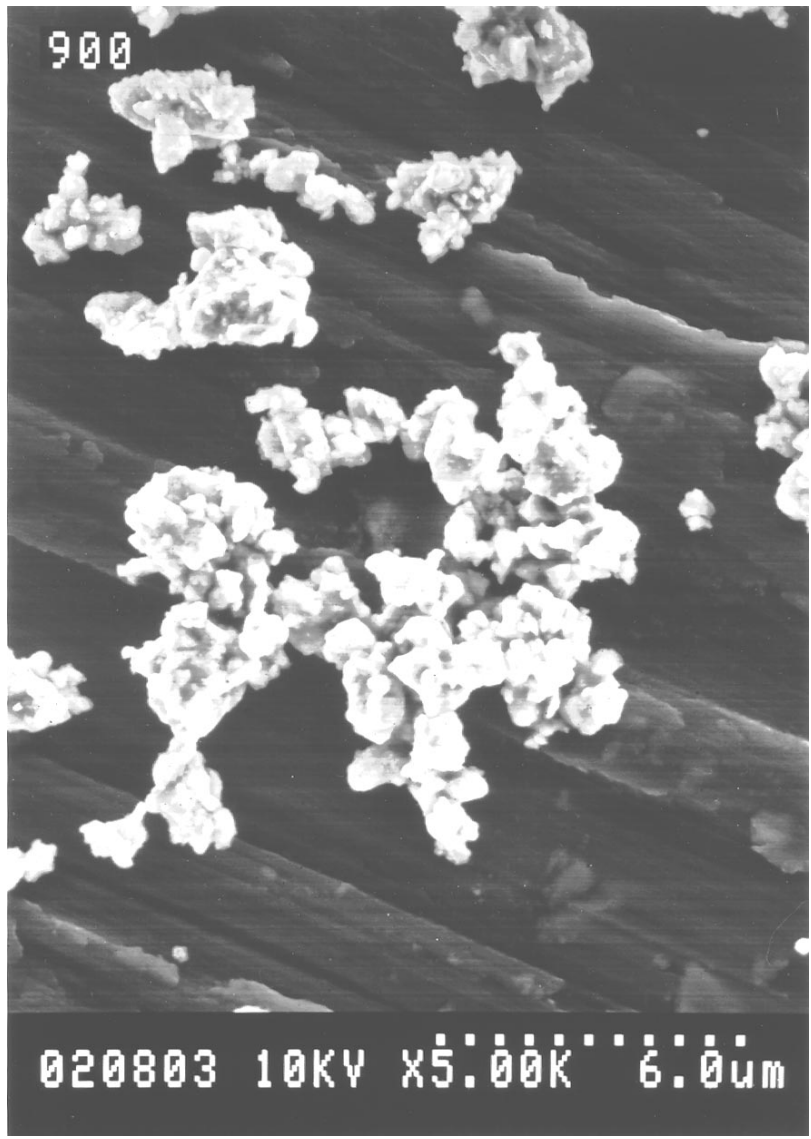

Fig. 4 SEM micrograph of $\mathrm{La}_{0.3} \mathrm{Sr}_{0.7} \mathrm{CoO}_{3-\delta}$ powder calcined at $900^{\circ} \mathrm{C}$

shows a SEM micrograph of a powder calcined at $900{ }^{\circ} \mathrm{C}$. The particle morphology shows agglomerates with an estimated size between 2 and $10 \mu \mathrm{m}$, which is agreement with that of the smaller particles in the corresponding size distribution given in Fig. 3. The laser scattering results suggest that some of the smaller agglomerates do form larger units. These are probably only relatively weak as they are no longer present after calcination at higher temperatures. Primary crystallite sizes of powders calcined at $1100^{\circ} \mathrm{C}$ of $35 \mathrm{~nm}$ were determined from the half peak width analysis of XRD patterns.

The X-ray diffractogram of a powder calcined for $5 \mathrm{~h}$ at $1100{ }^{\circ} \mathrm{C}$ could be indexed on the basis of a cubic lattice with unit cell length 3.8323(9) A. No additional lines were present. The cell volume is $56.283(3) \AA^{3}$ and the specific density $6.195 \mathrm{~g} \mathrm{~cm}^{-3}$, which was calculated assuming a composition with ideal oxygen stoichiometry $\mathrm{La}_{0.3} \mathrm{Sr}_{0.7} \mathrm{CoO}_{3}$. A full account of the XRD results is given elsewhere. ${ }^{9}$

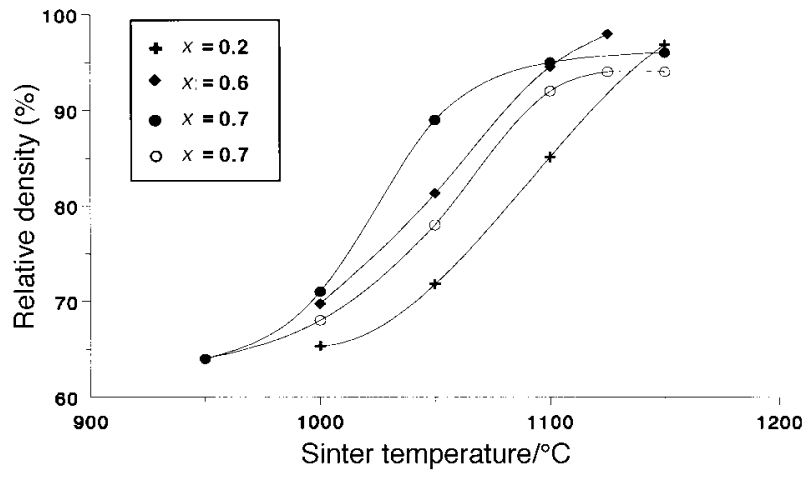

Fig. 5 Sinter curves for $\mathrm{La}_{1-x} \mathrm{Sr}_{x} \mathrm{CoO}_{3-\delta}(x=0.2,0.6$ and 0.7$)$ calcined at $920^{\circ} \mathrm{C}$ and for $x=0.7$ calcined at $950{ }^{\circ} \mathrm{C}$; sinter time $5 \mathrm{~h}$

\section{Sintering behaviour}

In Fig. 5, the sintering curve of $\mathrm{La}_{0.3} \mathrm{Sr}_{0.7} \mathrm{CoO}_{3-\delta}$ calcined at $920^{\circ} \mathrm{C}$ is shown. Data are compared with curves obtained for powders $\mathrm{La}_{1-x} \mathrm{Sr}_{x} \mathrm{CoO}_{3-\delta}$ with $x=0.2$ and 0.6 and with that for $\mathrm{La}_{0.3} \mathrm{Sr}_{0.7} \mathrm{CoO}_{3-\delta}$ calcined at $950{ }^{\circ} \mathrm{C}$. The sintering curves shift to higher temperatures with decreasing $\mathrm{Sr}$ content. Densities were obtained from rods sintered for $5 \mathrm{~h}$ using heating and cooling rates of $3{ }^{\circ} \mathrm{C} \mathrm{min}-1$. The sintering curve shifts to higher temperatures, and the final density decreases from $96 \%$ to $93 \%$ upon increasing the calcination temperature from $920-950{ }^{\circ} \mathrm{C}$. These results emphasize the precise control of the calcination temperature. Final densities for $\mathrm{La}_{0.3} \mathrm{Sr}_{0.7} \mathrm{CoO}_{3-\delta}$ powders calcined at $850^{\circ} \mathrm{C}$ and sintered at $1150{ }^{\circ} \mathrm{C}$ were observed to be $96 \%$. Fig. 6 shows a fracture surface of a sample $\mathrm{La}_{0.3} \mathrm{Sr}_{0.7} \mathrm{CoO}_{3-\delta}$ sintered at $1150^{\circ} \mathrm{C}$. The density of this sample, determined by the Archimedes method, was $95 \%$. As seen from Fig. 6, the residual porosity

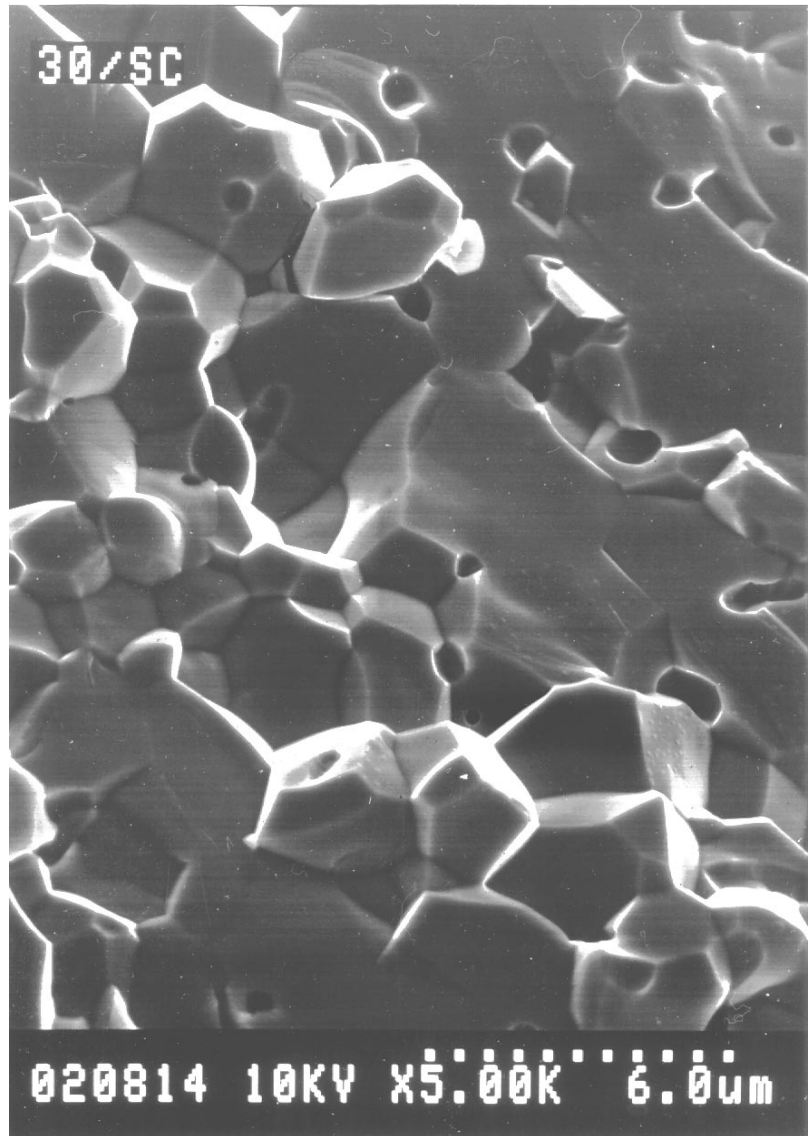

Fig. 6 SEM micrograph of a fractured surface of dense ceramics of $\mathrm{La}_{0.3} \mathrm{Sr}_{0.7} \mathrm{CoO}_{3-\delta}$ obtained after sintering at $1150{ }^{\circ} \mathrm{C}$ 
concentrates at or near the boundaries between grains. A uniform grain size of about $3 \mu \mathrm{m}$ is obtained after sintering while no indication is found of liquid phase sintering.

\section{Conclusions}

A method for the preparation of $\mathrm{La}_{0.3} \mathrm{Sr}_{0.7} \mathrm{CoO}_{3-\delta}$ powder is reported. It is shown that the pure perovskite phase is formed at temperatures above $850^{\circ} \mathrm{C}$. The powders are chemically homogeneous and characterized by a small primary crystallite size. The agglomerate size is of the order of $2-10 \mu \mathrm{m}$. The powders thus obtained possess a large sinterability enabling the consolidation into dense ceramics with relative densities over $96 \%$ after sintering at $1150{ }^{\circ} \mathrm{C}$.

\section{References}

1 Catalysis Today, 1990, 8[2]: Special issue, ed. M. Misono and E. A. Lombardo.
2 R. H. E. van Doorn, H. J. M. Bouwmeester and A. J. Burggraaf, Proc. Fall Meeting Electrochem. Soc., Chicago, Illinois, October 1995, ed. H. U. Anderson, A. C. Khandkar and M. Liu, The Electrochem. Soc. Inc., 1997, pp. 139-145.

3 H. J. M. Bouwmeester and A. J. Burggraaf, in CRC Handbook of Solid State Electrochemistry, ed. P. J. Gellings and H. J. M. Bouwmeester, CRC Press, Boca Raton, USA, 1997, pp. $481-553$.

4 T. Inoue, N. Seki, K. Eguchi and H. Arai, J. Electrochem. Soc., 1990, 137, 2523.

5 R. Mahendiran and A. K. Raychaudari, Phys. Rev. B, 1996, 54, 16044.

6 Traces, Diffraction Technology Pty. Ltd. Essington Street (P.O. Box 444), Mitchell, A.C.T. 2911, Australia.

7 D. H. A. Blank, H. Kruidhof and J. Flokstra, J. Phys. D, 1988, 21, 226.

8 M. J. Scholten, J. Schoonman, J. C. van Miltenburg and H. A. J. Oonk, Solid State Ionics, 1993, 61, 83.

9 R. H. E. van Doorn, J. Boeijsma and A. J. Burggraaf, Powder Diffraction, 1995, 10, 261

Paper 8/00500A; Received 19th January, 1998 